\title{
The determinants of vulnerability to currency crises: Country-specific factors versus regional factors ${ }^{1}$
}

\author{
Ping Wang ${ }^{a}$ and Tomoe Moore ${ }^{b}$ \\ ${ }^{a}$ Birmingham Business School, University of Birmingham, \\ Edgbaston, Birmingham B15 2TT, United Kingdom \\ Tel: +441214146675 \\ Fax: +441214146238 \\ p.wang.1@bham.ac.uk \\ ${ }^{b}$ Corresponding author \\ Department of Economics and Finance, Brunel University \\ Uxbridge, Middlesex, UB8 3PH, United Kingdom \\ Tel: +44 1895267531 \\ Fax: +441895269770 \\ tomoe.moore@brunel.ac.uk
}

\footnotetext{
${ }^{1}$ This is a revised version of the paper presented at the 8th Annual Meeting of the European Economics and Finance Society (EEFS), held at Warsaw, Poland in June, 2009. The authors are grateful to participants of this conference for their helpful comments. Thanks are also due to two anonymous referees of this journal for their helpful comments and suggestions. The usual disclaimer applies.
} 


\title{
The determinants of vulnerability to currency crises: Country-specific factors versus regional factors
}

\begin{abstract}
We investigate the determinants of exchange market pressures (EMP) for some new EU member states at both the national and regional levels, where macroeconomic and financial variables are considered as potential sources. The regional common factors are extracted from these variables by using dynamic factor analysis. The linear empirical analysis, in general, highlights the importance of country-specific factors to defend themselves against vulnerability in their external sectors. Yet, given a significant impact of the common component in credit on EMP, a contagion effect is apparent through the conduit of credit market integration across these countries under investigation.
\end{abstract}

Key words: Exchange market pressure; Dynamic factor analysis; New EU member states; Regional factors

JEL Classification: F3, 016 


\section{Introduction}

The currency crises, which occurred in Latin America, Central Europe and Asia in the 1990s had a large impact on the real economy, including a substantial loss of value of the domestic currency and a fall in output and employment. It has brought much attention in literature to their causes, consequences, and recommended responses. Much of the empirical literature on currency crises focuses on country-specific macroeconomic factors, in an attempt at signalling future currency crises.

In this vein, Eichengreen et al. (1996) make an early effort to identify currency crisis episodes by taking changes in exchange rates, international reserves and interest rates, which are combined into an index of speculative pressure known as the Exchange Market Pressure Index (EMPI). Since then, a substantial body of literature has followed by modifying the so-called 'early warning system', for example, Sachs et al (1996), Kaminsky et al. (1998), Berg et al. (2000) and Edison (2003), among others. More recently, Kamin et al. (2007), based on several probit models of currency crises, suggest that domestic factors have tended to contribute to much of the underlying vulnerability of emerging market countries, whereas adverse swings in external factors may have been important in pushing economies 'over the edge' and into currency crisis. Lin et al. (2008) apply the neuro fuzzy method, a hybrid of neural network and fuzzy logic, to construct an early warning system to predict a currency crisis and claim that their approach can provide better forecasting performance than those of signal approach, logit and neural network models. These empirical studies are based on the ad hoc threshold, which is defined in terms of a number of standard deviations above the mean to identify currency crises. Lestano and Jacobs (2007) employ the extreme value theory as an alternative in dating currency crises. A regime switching 
type of model has also been used in the literature to identify periods between tranquil and speculative attacks. In all, identifying currency crisis episodes plays a crucial role in these empirical studies.

It is important to emphasise that one of the main features of currency crises is the spill-over effect to neighbouring countries. Hence, many other studies have stressed the contagion effect, as seen from many crises of the 1990s, which tended to cluster within regions and affect a broad range of countries almost simultaneously. There have been a number of attempts to examine empirically the channels through which the disturbances are transmitted. Glick and Rose (1999) assert that the international trade linkage is related to the contagion, whereas macroeconomic and financial influences are not closely associated with the cross-country incidence of speculative attacks. Kaminsky and Reinhart (2000) find that the contagion channels come from both trade links and the financial sector links. Fratzscher (2003) examines the role of contagion in the currency crises by employing a nonlinear Markovswitching model to conduct a systematic comparison and evaluation of three distinct causes of currency crises: contagion, weak economic fundamentals, and 'sunspots' unobservable shifts in agents' beliefs. It is revealed that in the work of Fratzscher (2003), a high degree of real integration and financial interdependence among countries is a core explanation for recent emerging market crises. Mody and Taylor (2007) take an alternative view of the contagion effect by investigating regional vulnerability by examining several potential regional determinants for a group of Asian countries, and they find that the common factors have a significant impact on exchange market pressure (EMP).

In this paper, we investigate the determinants of country-specific vulnerability in terms of EMP by taking account of both the national and regional factors for the 
Czech Republic, Hungary, Poland, Slovakia and Slovenia over the sample period 1994 to 2006 on a monthly basis. ${ }^{2}$

The application of this study to these transition economies is based on the following grounds. Since the transition process from command to market regimes took place in the early 1990s, these economies have experienced varying exchange rate regimes. In the earlier period, they suffered from the surge of price increases following market liberalisation. The fixed regime was an initial step in an antiinflation strategy for some transition economies, and as the transition process progressed, managed flexible exchange rates or widening the bands were often introduced, in particular, for these countries under current study. ${ }^{3}$ The unsettling exchange rate regimes along with the economic structural reforms including the massive privatisation and market opening policy have exposed these economies to vulnerability to external shocks. It is also noted that currency crises are likely to coexist with banking crises (Kaminsky and Reinhard 1999). These transition countries experienced some sort of banking sector crisis at different points in time in the early 1990's. At the start of the transition period, independent commercial banks were created from a former monobank system, and the newly established banks had, in effect, little capability of appraising projects.

Moreover, in emerging economies, government and firms tend to rely on foreign currency denominated debt, hence the exchange rate changes can have a

\footnotetext{
${ }^{2}$ We focus on the 'first' wave of new EU member states in the CEE region, which are the largest by the GDP measure and geographically close to each other.

${ }^{3}$ Hungary and Poland went from a fixed exchange rate regime with varying bands to a managed or full floating rate system. In the case of the Czech Republic and Slovakia, the currency crises forced them to introduce floating exchange rates. The Maastricht exchange rate criterion implies a participation in the ERM II for new EU countries as a prerequisite to joining the single currency. Slovenia opted for the ERM II in 2004 from the managed floating system, and joined the euro in 2007. Slovakia also adopted the euro in January 2009.
} 
significant impact on debtors' balance sheets or the profitability of banks (Amato and Gerlach 2002). Consequently, the stable exchange rates are one of the major factors to prevent banking crises.

It is, therefore, imperative to investigate the forces driving the pressure on their foreign exchange markets, yet the empirical literature on EMP applied to the Central Eastern European countries (CEEC) is very limited, except for the works of Van Poeck et al. (2007) and Stavárek (2008). ${ }^{4}$

The methodology adopted in this paper is systematic. Firstly, we derive EMP for individual countries, which represents the local vulnerability. Secondly, we extract the common component of the EMP from this group of countries by using dynamic factor analysis. The extracted common factor is treated as a regional stress index, referred to as regional vulnerability. Thirdly, we explore the potential determinants of national and regional EMPs. From the country-specific determinants (i.e. national factors), we extract the common components (i.e. common factors) by using the same dynamic analysis. Finally, a linear regression analysis is conducted to investigate the driving forces behind the national vulnerability (i.e. national EMP) by specifying the national and common factors. In this way, we are able to identify the main determinants of EMP for each country in two dimensions at national or regional levels ${ }^{5}$. The common factors are also used to measure the determinants of the regional stress index.

\footnotetext{
${ }^{4}$ Note that Stavárek (2008) focuses on the model comparison of deriving EMP, which is different from our objective in this paper. Although Van Poeck, et al. (2007) analyse the determinants of EMP for eight CEEC countries, their study is confined to country-specific factors without paying attention to regional factors. A number of observations is also rather limited by using quarterly data over the period 1990 and 2003.

${ }^{5}$ In the early warning literature, discrete models are often employed in the empirical work. It is argued that a discrete measure of crises in the binary models leads to a loss of information on the scale of
} 
The main objective of this paper is to investigate to what extent the countryspecific factors and regional common factors, respectively, contribute to the vulnerability. As potential factors, we consider the fundamental macroeconomic and financial variables (e.g. Krugman 1979) ${ }^{6}$, and the balance sheet effects of currency mismatches (e.g Eichengreen and Hausmann 1999) together with the self-fulfilling nature of speculative attacks (Obstfeld 1996). Such an analysis, we believe, would make a valuable contribution to delivering clear policy options concerning the course of action to defend their external sector.

The empirical evidence seems to highlight the importance of country-specific factors to guard against the vulnerability of their external sector. Yet, we find the statistically significant impact of the common component in credit on the EMP for all of these economies, indicating that there is a contagion effect observed through the conduit of credit market integration across these countries.

The rest of the paper is organised as follows. Section 2 outlines the derivation of EMP and the specification of dynamic factor analysis, which is used in extracting the regional stress index and the common factors of determinants of vulnerability. Section 3 reports the data used in this study. Empirical study, together with the discussion of the results is presented in Section 4. Section 5 deals with the conclusion.

\footnotetext{
speculative pressure, as it excludes incidents below the arbitrary threshold value. Such a constraint is avoided in the linear regression. In recent years, Markov switching model (MSM) has been applied to the currency crisis analysis. The MSM may have the ability of detecting the turning points between tranquil and speculative attack periods that are indicated by low and high regimes of volatility in EMP, respectively. The major limitation in the MSM is that it is extremely difficult to obtain a plausible result by specifying all potential determinants in the model. We resort our empirical analysis to the linear model.

${ }^{6}$ For example, it is argued that crises were associated with expansionary monetary and fiscal policies and also excessive domestic credit, leading to a substantial loss of foreign reserves under a fixed exchange rate regime (Krugman 1979).
} 


\section{Exchange market pressure and dynamic factor analysis}

The concept of exchange market pressure (EMP) was originally proposed by Girton and Roper (1977) in order to capture the idea of devaluation probability and financial stress. The monetary authorities, in general, defend against depreciation by policy measures, such as setting a higher official interest rate or buying domestic currency in the foreign exchange market. EMP measures the depreciation-counteracting policy actions, for instance see IMF (2007) who studied adequate policy responses to surges in capital inflows using EMP. On the other hand, EMP better signals foreign exchange market tensions than the movement of exchange rates, hence it contributes to providing policy makers to timely counteract contagion from other countries and speculators to find profitable opportunities. A crucial element in the EMP definition is that EMP itself is a counterfactual concept, i.e. it is the hypothetical situation where the central bank tries to influence the exchange rate (Weymark, 1995). This makes EMP unobservable. However, we can observe the policy responses to pressure, besides the changes in exchange rates, which provides an opportunity to quantify EMP in an indirect way.

EMP is proxied by a weighted average of percentage changes in the exchange rate and (the negative of) percentage changes in international reserves. Eichengreen et al. (1996) modify EMP by including the level of domestic interest rates in the construction of the index because policy makers could also resort to raising interest rates to defend their currency ${ }^{7}$. Thus, an increase in the value of a country's EMP indicates that the net demand for that country's currency is weakening and that the currency may be susceptible to a speculative attack, or that such an attack is already

\footnotetext{
${ }^{7}$ Kaminsky et al. (1998) follow the concept of Eichengreen et al., though without specifying interest rate differentials in their index. Edison (2003) extends the country coverage and adds several explanatory variables to develop this monitor system.
} 
under way (Mody and Taylor 2007). Weymark (1997) extended EMP based on rational expectation and small open economy monetary model, where the bilateral and multilateral intervention by the Canadian central bank was measured. Pentecost et al. (2001) applied EMP to the principal components analysis where it is found to be explained by the variation of the money supply, long-term interest rate, the depreciation of real exchange rate, the level of budget constraints, and the current account for some EU countries. Another strand of the literature focuses on the relationship between the authority reaction and EMP, for example, Kenneally and Nhan (1986) examined the stability in relation to the monetary variables for Canada, Britain, France and Switzerland. The evidence reveals that the domestic credit policy has the most important role for maintaining a country's foreign exchange market pressure. Tanner (2001) finds that monetary policy has a significant influence on the foreign exchange market pressure, and tightening monetary policy will contribute to reducing it. In this paper, we specify EMP following Eichengreen et al. (1996) and we analyse determinants of vulnerability to currency crises by applying it to the dynamic factor model.

The exchange market pressure for a country $i$ at time $t$, denoted $e m p_{i t}$, can be constructed as:

$$
e m p_{i t}=\alpha \frac{\Delta e_{i t}}{e_{i t}}-\beta \frac{\Delta r_{i t}}{r_{i t}}+\gamma \Delta i_{i t}
$$

where $e_{i t}, r_{i t}$ and $i_{i t}$ denote, respectively, the nominal exchange rate (domestic price of foreign currency), level of foreign exchange reserves and short-term interest rates. $\Delta$ denotes the first-difference operator. The weights $\alpha, \beta$ and $\gamma$ are chosen such that each of the three components on the right-hand side of equation (1) has a standard deviation of unity, which prevents any one of them from dominating the index. 
The common component of EMP (or the regional stress index) is extracted from the individual EMPs of five countries by using the dynamic factor model. The same method is applied to derive the common component of the potential determinants of the EMP. Suppose that $e m p_{i t}$ is the EMP at time $t$ for $i$ country. It can be modelled as consisting of two stochastic autoregressive (AR) processes: a single unobserved component, which corresponds to the common factor, and an idiosyncratic component, representing a country-specific factor. The model can be written as follows,

$$
\begin{array}{ll}
e m p_{i t}=\lambda_{i} \kappa_{t}+z_{i t}, & i=1, \ldots, n, \\
\phi(L) \kappa_{t}=v_{t}, & v_{t} \sim \text { i.i.d. } N(0,1), \\
\psi_{i}(L) z_{i t}=\varepsilon_{i t}, & \varepsilon_{i t} \sim \text { i.i.d. } N\left(0, \sigma_{i}^{2}\right)
\end{array}
$$

where $\kappa_{t}$ is the common factor of EMP to all of the countries under examination and it enters into each of the $n$ equations with a different weight $\lambda_{i}$, which measures the sensitivity of the $i$ th country to the regional stress index. The variables $z_{i t}$ are idiosyncratic terms having an $\mathrm{AR}$ representation. Their innovations $\varepsilon_{i t}$ can be thought of as measurement errors and $v_{t}$ is the innovation to the common factor. The functions $\psi_{i}(L)$ and $\phi(L)$ are polynomials in the lag operator, where $L$ is the lag operator.

To facilitate estimation, the model can be expressed in state-space representation. The $\mathrm{AR}(2)$ is adopted without losing the generosity, since the second order is found to be more appropriate in applying to the potential determinants of macroeconomic and financial variables in Section 4.2. With the $\operatorname{AR}(2)$ process for 
both the common factor and idiosyncratic term, and with $n=5$, the model can be expressed as the measurement and transition equations ${ }^{8}$.

$$
\left[\begin{array}{l}
e m p_{1 t} \\
e m p_{2 t} \\
e m p_{3 t} \\
e m p_{4 t} \\
e m p_{5 t}
\end{array}\right]=\left[\begin{array}{llllllllllll}
\lambda_{1} & 0 & 1 & 0 & 0 & 0 & 0 & 0 & 0 & 0 & 0 & 0 \\
\lambda_{2} & 0 & 0 & 0 & 1 & 0 & 0 & 0 & 0 & 0 & 0 & 0 \\
\lambda_{3} & 0 & 0 & 0 & 0 & 0 & 1 & 0 & 0 & 0 & 0 & 0 \\
\lambda_{4} & 0 & 0 & 0 & 0 & 0 & 0 & 0 & 1 & 0 & 0 & 0 \\
\lambda_{5} & 0 & 0 & 0 & 0 & 0 & 0 & 0 & 0 & 0 & 0 & 0
\end{array}\right]\left[\begin{array}{l}
\kappa_{t} \\
\kappa_{t-1} \\
e_{1 t} \\
e_{1, t-1} \\
e_{2 t} \\
e_{2, t-1} \\
e_{3 t} \\
e_{3, t-1} \\
e_{4 t} \\
e_{4, t-1} \\
e_{5 t} \\
e_{5, t-1}
\end{array}\right]
$$

$$
\left[\begin{array}{l}
\kappa_{t} \\
\kappa_{t-1} \\
z_{1 t} \\
z_{1, t-1} \\
z_{2 t} \\
z_{2, t-1} \\
z_{3 t} \\
z_{3, t-1} \\
z_{4 t} \\
z_{4, t-1} \\
z_{5 t} \\
z_{5, t-1}
\end{array}\right]=\left[\begin{array}{ccccccc}
\phi_{1} & \phi_{2} & 0 & 0 & \ldots & 0 & 0 \\
1 & 0 & 0 & 0 & \ldots & 0 & 0 \\
0 & 0 & \psi_{11} & \psi_{12} & \ldots & 0 & 0 \\
0 & 0 & 1 & 0 & \ldots & 0 & 0 \\
\vdots & \vdots & \vdots & \vdots & \ddots & \vdots & \vdots \\
0 & 0 & 0 & 0 & \ldots & \psi_{51} & \psi_{52} \\
0 & 0 & 0 & 0 & \ldots & 1 & 0
\end{array}\right]\left[\begin{array}{c}
\kappa_{t-1} \\
\kappa_{t-2} \\
z_{1, t-1} \\
z_{1, t-2} \\
z_{2, t-1} \\
z_{2, t-2} \\
z_{3, t-1} \\
z_{3, t-2} \\
z_{4, t-1} \\
z_{4, t-2} \\
z_{5, t-1} \\
z_{5, t-2}
\end{array}\right]+\left[\begin{array}{c}
v_{t} \\
0 \\
\varepsilon_{1 t} \\
0 \\
\varepsilon_{2 t} \\
0 \\
\varepsilon_{3 t} \\
0 \\
\varepsilon_{4 t} \\
0 \\
\varepsilon_{5 t} \\
0
\end{array}\right]
$$

Using the Kalman filter technique and maximum likelihood estimation, the unobservable component, $\kappa_{t}$, together with the parameters can be derived.

\footnotetext{
${ }^{8}$ Any lags that have more than 2 would make the computation inapplicable since there are five factors included in the dynamic factor model in this paper.
} 


\section{Data}

The datasets used in this study are the monthly data during the period from January 1994 to December 2006 with 156 observations for the Czech Republic, Hungary, Poland, Slovakia and Slovenia. The sample period ends in December 2006, since Slovenia joined the euro in January, 2007. The detailed description of all data series and their sources (including the determinants of EMP as described below) can be found in Appendix. The nominal exchange rate is the number of domestic currency per US\$ and per ECU/Euro. ${ }^{9}$ These countries used to peg the DM and the US\$ with a ratio of around $70-60 \%$ and $30-40 \%$ respectively till around 1999/2000. We, therefore, take weights in exchange rates with $65 \%$ of ECU/Euro and $35 \%$ of US\$, and this reflects their concern relative to two major currencies over the sample period.

\section{Results}

\subsection{Exchange market pressure and the extracted common factor}

\section{[FIGURE 1 AROUND HERE]}

The constructed EMP over the sample period for each country, based on equation (1), is shown at the top of each graph with the right-hand side scale in Figure 1 together with the extracted common component of EMP with the left-hand side scale, representing the regional stress index ${ }^{10}$, at the bottom for comparison. A large positive value of EMP suggests that the country is under higher stress of depreciation, whereas a negative value indicates speculators' expectations of currency appreciation. Looking at the individual EMPs, it is evident that each country experienced a different degree of stress at different periods. During the early period Hungary, Poland,

\footnotetext{
${ }^{9}$ Until the end of 1998, the exchange rate is against the ECU and after that, with the Euro.

${ }^{10}$ Note that the regional stress index, or the common EMP is the same for all five countries.
} 
Slovakia and Slovenia experienced a high and/or volatile EMP, whilst for the Czech Republic and, again, Slovakia it showed a high pressure in 1997 and 1998. The former appears to reflect the transition process of these economies. The latter indicates a high tension before the actual currency crises occurred in the Czech Republic and Slovakia, where the fixed exchange rate became unsustainable. Since 2000, the EMPs have been shown to be less volatile except for Hungary during the period around 2003.

From the plotted regional stress index, we can see that the highest tension occurred during the period 1997-98, which echoes the depreciation pressure throughout these emerging markets and coincides with the financial crises in Asia and Russia. It is also notable that since 2000 there is a downward trend till around 2003, and the regional stress index is mostly negative. The negative value is an indication of regional optimism from the point of view of international investors (Mody and Taylor, 2007).

The pattern over time of the regional stress index, in general, appears to be quite different from the individual EMPs until around in 2004, when these economies joined the EU ${ }^{11}$. After that, the common EMP appears to depict a similar pattern of fluctuations with the individual EMPs.

\section{[TABLE 1 AROUND HERE]}

Table 1 reports the estimates of the parameters of the state space models (2) (4). It is shown that the estimated $\lambda_{i}$ parameters, which measure the degree of influence of the regional stress index on the national EMP, are all statistically significant at the 5 percent level. This implies that the regional stress index plays an

\footnotetext{
${ }^{11}$ This evidence provides the meaningfulness of modelling the determinants of individual EMPs based on both country-specific factors and common factors.
} 
important role in driving the EMP for each of the countries under examination. In order to investigate the extent of the variation in each country's EMP explained by the regional stress index, we further regress the individual EMPs onto the extracted regional EMP, and present the goodness of fit, $R^{2}$ statistics in the last column of Table 1. The Czech Republic is shown to have at the highest with an $R^{2}$ of 65 percent, whereas Hungary has the lowest with only 6 percent. This appears to reflect that the Czech Republic is the most vulnerable to the regional movement, whereas Hungary is the least exposed to the regional stress index.

\subsection{The determinants of exchange market pressure}

To investigate the driving force behind both the country specific EMP and the regional stress index, we consider a number of macroeconomic and financial variables as potential determinants.

It is argued that a currency crisis is the interaction of high interest rates and capital flight caused by the combination of currency collapse and banking failure. Capital flight is likely to be translated into the collapse of currency value, which in turn implies that investors require a higher risk premium, giving rise to ever higher interest rates. With a rising cost of capital, and foreign currency denominated debt obligations doubled or tripled in terms of local currency, banks are framed with ever increasing nonperforming assets and default of loans, whilst bearing huge foreign debt burdens. One of the common preconditions for such a crisis is, inter alia, massive capital inflows: a high level of foreign borrowing in the short-term tends to lead to a currency crisis, and the crisis is a sudden withdrawal of foreign capital creating a liquidity crisis (e.g. Obstfeld 1986 and 1996 and Radelet and Sachs 1998). It is often the case that the crises tend to occur following privatization, deregulation and 
financial liberalisation, since such structural reforms attract foreign capital. It is, therefore, conceivable that the effect of an increase in foreign liabilities on EMP is detrimental for these transition economies.

Note that the influence of capital flows can be better measured by controlling the level of foreign direct investments (FDI). FDI is a long term investment, and it is important to distinguish between the long-term and short-term private capital flows, and to explore the differential effect on EMP. FDI consists of not only capital per se, but also management skills and technology, and that FDI generates technological diffusion from the developed to the emerging economies raising economic growth ${ }^{12}$. In this respect, it is expected a negative effect on EMP.

The capital outflows correspond to currency depreciation pressure, yet during the fixed or managed exchange rate regimes, central banks would intervene to maintain the level of exchange rates by buying domestic currency in exchange for foreign reserves. The effect of the intervention would be a decline in domestic money supply (though if there aren't enough reserves, the value of the currency falls), and a fall in money supply corresponds to a rise in interest rates, hence a rise of EMP. This mechanism predicts a negative impact of money on EMP.

We also consider stock prices as one of the determinants of EMP. Although all stock markets were closed during the Communist period, stock exchanges reemerged with mass privatization programmes in the early 1990s. The earlier stage of these stock markets was characterised by the lack of an adequate regulatory framework, and the requirement of disclosure and the high cost of raising funds through the market deterred the development of stock market (Wang and Moore, 2009). These emerging markets experienced a stock market growth over the sample

\footnotetext{
${ }^{12}$ See Mallick and Moore (2008) for the extensive empirical work for 60 developing countries.
} 
period, though not necessarily driven by fundamentals, and during the Asian and Russian financial crises, these stock markets experienced high volatility. ${ }^{13}$ Note that it is empirically found that the volatile movement of stock markets can be a cause of currency crisis (Kaminsky et al. 1998 and Sarno and Taylor 1999), especially when the market plummets, hence asset prices could be a strong candidate to explain the $\mathrm{EMP}^{14}$. Note also that there is evidence of significant spillover effects from developed to these transition markets, hence, a strong association between stock prices and EMP is expected (Hanousek et. al. 2009 and Kocenda and Hanousek 2011).

It is generally expected that monetary policy affects the EMP, and Tanner (2001) theoretically and empirically finds that the monetary policy stance is measured by domestic credit growth, often associated with a loosening lending practice by banks. A rapid credit growth is a feature of currency crises in many countries. Note also that the impact of domestic credit is likely to depend on the stage of the business cycle. Hence, credit as percentage of GDP is also considered as one of the sources of EMP.

Finally, import prices are deemed as one of the determinants of the EMP. For small open economies, import prices may act as a conduit for inflationary pressures, which are then transmitted into the EMP. Oil prices are included as a proxy of import prices.

To summarise, the linear equation takes the following form with the predicted sign:

\footnotetext{
13 See Moore and Wang (2007) and Wang and Moore (2009).

14 Mody and Taylor (2007) attribute this to the moral hazard problem existing where financial institutions provide loans to finance risky financial assets, causing asset inflation beyond the level of fundamentals. When the bubble bursts, the consequence is capital flight triggering a currency crisis.
} 


$$
\begin{aligned}
& E M P=f\left(e^{2 m p_{t-1}}, s p, f l, f d i, d c, d c y, m, o i l, s p^{c f}, f l^{c f} d c^{c f}, d c y^{c f}, m^{c f}\right) \\
& f_{s p}<0, f_{f l}>0, f_{f d i}<0, f_{d c}>0, f_{d c y}>0 f_{m}<0, f_{o i l}>0,
\end{aligned}
$$

where $s p$ is the log of real stock market index adjusted by consumer price index; $d c$ is the growth of real domestic credit ; $d c y$ is the log ratio of credit to GDP. $m$ is the $\log$ ratio of M2 to GDP, $f l$ is the log ratio of total foreign liability to money stock, $f d i$ is the log ratio of net FDI flows to GDP and oil is the log of oil prices. The lagged dependent variable, $\boldsymbol{e m p}_{t-1}$ is also specified in order to capture either adjustment or persistent effects from the past movement of EMP. The common factors of these variables are notated with the superscript ' $c f$ '. The data are all first-differenced to ensure stationarity. ${ }^{15}$

The common factors are extracted using the Kalman filter technique, the same state space models of (2) - (6) used for the extraction of regional vulnerability index. The results are found in Table $2^{16}$. They are, then, used to investigate the predicative components of regional and national vulnerabilities.

\section{(TABLE 2 AROUND HERE)}

It is shown that the measure of the influence of the regional factors on the country-specific factors, i.e. $\lambda_{i}$ is well determined with being mostly statistically significant at the 5 percent level. The results demonstrate that the common factors of the determinants matter in the real and financial sectors of these economies.

The equation (7) is utilised for modelling each country's EMP by specifying both country-specific variables, and the common variables. We examine the extent to

\footnotetext{
${ }^{15}$ We have checked the variables by the Augmented Dickey Fuller unit root test.

${ }^{16}$ In terms of $f l$, we extracted the common factor from the ratio of financial liability to GDP, rather than from the ratio of financial liability to money stock. This is due to the fact that the latter fails to converge in the dynamic factor model, and we were unable to obtain the common factor. As to fdi, the data are only available annually, hence we only specify the country-specific $f d i$.
} 
which the determinants between country-specific and regional factors play an important role in inducing each country's crisis. We also estimate the regional stress index by regressing the common EMP on common factors.

Given the fact that there are potential multicollenearity problem between country-specific and common factor variables, the estimation is conducted with the general to specific method, where the explanatory variables that fail to reach around the 20 percent significant level are deleted. The parsimonious models for the EMPs are shown in Tables 3 .

\section{[TABLE 3 AROUND HERE]}

Diagnostic tests for serial correlation by the Breusch-Godfrey test indicate the absence of serial correlation at the conventional significance level. Where the heteroskedasticity test by the Breusch-Pagan-Godrey method rejects the null of homoskedasticity, we use robust estimation with White's heteroskedastic consistent tratio. The Hausman exogeneity test with two lagged values of all variables in (7) as the instrument sets is satisfactory to prove that the regressors are likely to be exogenous.

\section{[TABLE 4 AND FIGURE 2 AROUND HERE]}

These transition economies have undergone substantial structural changes in their economies in the estimation period. We, therefore, carried out a series of Chow forecast tests to check slope coefficients for structural breaks (Bai 1996). We chose five potential breakpoints (one every two years) making five tests in each equation ${ }^{17}$. We also conducted the Quandt-Andrews breakpoint test tests for unknown structural breakpoints in the sample (Andrews, 1993). The results are shown in Table 4. Furthermore, in order to examine the parameter stability, CUSUM test that is based

\footnotetext{
${ }^{17}$ This is a test for breaks without known break dates. We tested for every year to find insignificant structural shifts, but in order to save space, we only present the test for every two years.
} 
on the cumulative sum of the recursive residuals is presented in Figure 2. This plots the cumulative sum together with the $5 \%$ critical lines.

Both breakpoint tests in Table 4 appear to suggest that there is no structural break in the estimates over the sample period. The results seem to indicate that any potential shifts over the sample period may have been subsumed among the proposed determinants ${ }^{18}$. The CUSUM test in Figure 2 also suggests the absence of the parameter instability, since the cumulative sum remains inside the area between the two critical lines. Overall, these diagnostics tests suggest that the underlying parameter estimates are remarkably robust for us to draw inferences from the estimates $^{19}$.

It is found that the coefficient of $e m p_{t-1}$ is significantly positive in the Czech Republic, implying that the movement of emp can be persistent in one direction without an adjustment effect. This appears to support the self-fulfilling nature of speculative attacks, characterising the currency crisis experienced in this country. Poland and Slovenia have shown such a nature, but at a lower level of statistical significance. Obstfeld (1996) emphasizes endogenous economic policies and agents' expectations: Policymakers respond to changes in the economy, and agents' expectations are formed based on such a relationship, and these expectations, in turn, affect some variables to which policymakers again react. Henceforth, this circularity gives rise to self-fulfilling crises.

With respect to the country-specific determinants, the sign on the coefficients is in line with the prediction. The negative effect of real growth in the stock price

\footnotetext{
${ }^{18}$ It is likely that the explanatory variables that are specified in the model such as stock prices and domestic credit themselves take account of the structural shifts.

${ }^{19}$ It is, however, noted that the model may potentially suffer from inconsistency problem, since the common factors are the estimates. This caveat should be born in mind in interpreting the empirical results.
} 
index is observed in all cases, and it proves that the contraction of a stock market exerts a detrimental effect on national currencies by increasing emp. The substitution effect from domestic to foreign assets by investors seems to be evident.

A highly statistically significant coefficient on foreign liability $(f l)$ is found in Hungary. There was the ease of availability of external funds in Hungary compared with the other four countries: the rights of foreign shareholders under Hungarian law in Hungarian firms created a strong connection between privatization and foreign direct investment, making it easy to obtain external funds from abroad. Also note that Hungary bankrolled its expansion with foreign loans, generating vulnerability to external borrowing.

There seems to be a discernible impact of credit through either $d c$ or $d c y$ on the emp, since statistically, at least at the $10 \%$ level, and numerically significant positive coefficients are found for all economies under investigation. For these transition economies, credit growth or credit with the excess of GDP growth may be one of the main causes of vulnerability. This is not surprising given the following reason. The credit markets in transition economies were, in general, characterised by soft budget constraints (SBCs). SBCs imply that governments or financial institutions are willing to provide additional resources to firms, especially, to former state-owned enterprises, or to bail them out (Kornai, 1992 and Lízal and Svejnar, 2002). Evidence indicates that soft budget constraints remained during the later stages of transition, since subsidies through banks continued to exist on a large scale (Lízal and Svejnar 2002 and Konings et al. 2003). The transition countries are, therefore, prone to excessive government deficits, building up high levels of public debt. It is also a cause of financial bubbles (Kornai 2001 and Brücker et al. 2005), and a growth of domestic credit is a concern in potentially driving exchange market pressure. 
The impact of monetary growth is significant, except for Slovakia. The negative sign could possibly be due to the intervention by the central banks in an attempt to maintain exchange rates in the foreign exchange market affecting the money supply with the consequence of higher interest rates. However, the expected impact is far from unambiguous depending on, inter alia, central banks' sterilization policies $^{20}$. It is also possible that interest rates are raised due to a higher rate of inflation, and the contractionary monetary policy, in turn, reduces the monetary growth. The Czech Republic and Poland respond to the oil price, and high import prices are likely to be a cause of stress for their external sector.

We now turn to the common factor variables with the superscript ' $c f$ ' in Table 3. One can see that the regional emp in the last column is largely explained by stock prices and credit. This applies to country-specific EMPs, in particular, the role of credit is explicit being the robust driving force of the these EMPs. This reemphasises the credit expansion scenario of crises for emerging economies. For example, heavy reliance on capital inflows as a main source of high levels of domestic credit rendered the Asian market vulnerable; it was seen that massive outflows of portfolio assets and credit gave rise to the collapse of the domestic currency. In our study, the significant effect of common factor of credit implies that the contagion effect of currency crisis from one economy to another economy may arise from the expansion of credit. This accords with Kaminsky and Reinhart (2000) and Fratzscher (2003), who find the financial sector links or financial interdependence amongst countries as one of the main causes for recent emerging market crises.

For the five national EMP regressions, the magnitudes of the coefficients of common factors are far smaller than those of national factors. This is not

\footnotetext{
${ }^{20}$ It is also argued that central banks of these countries have not much intervened in the foreign exchange market.
} 
unanticipated. The complexity of foreign sector attached to individual countries combined with naïve and heterogeneous economic structure may demonstrate the significant effect of country-specific factors. The evidence confirms that national factors are more important than regional ones in explaining the individual EMPs. Yet, there appears to be some integration for these transition economies as to be explained by the regional factor. These countries may embrace some harmony in order to defend themselves against vulnerability in their external sectors.

\section{Conclusion}

We have investigated the determinants of exchange market pressure for the transition economies by specifying both country-specific and regional common factors. In the existing literature, most researchers focus on internal factors in the belief that certain fundamental domestic factors affect a country's external sector, at the same time many other observers stress the importance of contagious elements in global markets as being responsible for external vulnerability. In our study, the sensitivity of national EMPs to the regional EMP is found to be statistically significant, implying that the regional stress induces an increase in national vulnerability. We also find a relatively strong impact of the regional credit on driving the regional and the national EMPs. In this respect, although the linear empirical analysis, in general, highlights that the country-specific determinants are more crucial in explaining the vulnerability in foreign exchange markets for these five new EU countries, we can not ignore the contagion effect on national vulnerability.

In light of the findings in this study, the key policy implications may be drawn up as follows: A fall in stock prices is likely to be one of the causes of currency crisis for these economies, which was commonly found in crisis-hit emerging markets. The 
movements of stock prices at a national level are to be closely monitored. Hungary and Slovakia need to be alert that a fall in regional stock prices is also a concern for a higher EMP. The level of money stock may also matter for a sustainable exchange rate market. There is a need of coordinated action between monetary policy and the central banks' sterilisation policy. Credit both at national and regional levels is one of the main concerns for all economies under investigation. In particular, the finding of the significant common credit factor indicates the tendency of obtaining credit from abroad in this region, and the excess of foreign debt may induce a crisis ${ }^{21}$. This is to be strictly scrutinised, for instances, to rely heavily on foreign ownership of banks for loans or external finance would make the currency vulnerable to a sharp depreciation.

Further study in other regions would be worthwhile.

\section{Appendix}

\section{Description of the data}

Data are collected from International Financial Statistics (code) and Datastream (DS):

National currency per US\$ (rf, IFS ). Nominal exchange rate with ecu/euro (DS). Foreign exchange reserves (id.d, IFS). Foreign liabilities (16c, IFS). Domestic credit (32, IFS). Consumer price index (64, IFS). Money plus quasi money (35L, IFS) for the Czech, Poland and Slovakia and M2 (DS) for Hungary and Base money (DS) for Slovenia. Industrial production (66, IFS) is used for GDP. Crude oil-Brent FOB US\$ per Barrel (DS). Short term interest rates (DS). Share prices index (62) for Poland and

\footnotetext{
${ }^{21}$ Hungary's banking system was heavily exposed to foreign financing at a time when investors were pulling back from emerging economies during the financial crisis of October 2008. Hungary became the first European Union country to finalise an emergency rescue by securing $\$ 25$ billion from the IMF, the EU and the World Bank.
} 
DS market for the Czech republic and Hungary, SAX 16 for Slovakia and Slovenian Exchange Stock for Slovenia.

Some parts of data are calibrated as follows:

Monthly data for Financial liabilities (16c) and Domestic credit (32) in Hungary are not available during 1994:01 to 1999:12. The monthly data are interpolated from the corresponding quarterly series applying a linear technique. Monthly data of Domestic credit (32) are not available during 2005:1 to 2005:12. The missing data are calibrated proportionately with the same rate of growth as the data for Domestic credit to private sector $(32 \mathrm{~d})$.

\section{References}

Amato JD, Gerlach S (2002). Inflation targeting in emerging market and transition economies: Lessons after a decade, European Economic Review, 46, 781-790.

Andrews DW K (1993). Tests for parameter instability and structural change with unknown change point, Econometrica, 61(4), 821-856.

Bai J (1996)/ Estimation of a change point in multiple regression model, Review of Economics and Statistics, 79, 551-563.

Berg A, Borensztein E, Milesi-Ferreti GM, Pattillo C (2000). Anticipating balance of payment crises: The role of early warning systems, IMF Occasion Paper 186.

Bonin JP, Schaffer ME (2002). Revisiting Hungary's bankruptcy episode. In: Meyendorff, A, Thakor, A. (Eds.), Designing financial systems in transition economies: Strategies for reform in Central and Eastern Europe, 59-99.

Cerra V, Saxena SC (2002). Contagion, monsoons, and domestic turmoil in Indonesia's currency crisis, Review of International Economics, 10(1), 36-44.

Edison HJ (2003). Do indicators of financial crises work? An evaluation of an early warning system, International Journal of Finance \& Economics, 8, 11-53. 
Eichengreen B, Hausmann R (1999). Exchange rates and financial fragility, NBER Working Papers 7418, also in Proceedings, Federal Reserve Bank of Kansas City, 329-368

Eichengreen B, Rose AK, Wyplosz C (1996). Contagious currency crises. Scandinavian Journal of Economics, 98, 463-484.

Flood R, Marion N (1998). Perspectives on the recent currency crisis literature, IMF working paper WP/98/130.

Fratzscher M (2003). On currency crises and contagion, International Journal of Finance \& Economics, 8, 109-129.

Girton L, Roper D (1977). A monetary model of exchange market pressure applied to the post-war Canadian experience. American Economic Review, 67, 537-548.

Glick R, Rose AK (1999). Contagion and trade: Why are currency crises regional? Journal of International Money and Finance, 18, 603-617.

Hanousek J, Kocenda E, Kutan AM (2009). The reaction of asset prices to macroeconomic announcements in new EU markets: Evidence from intraday data. Journal of Financial Stability, 5(2), 199-219.

Hansen B E (1997). Approximate asymptotic P-values for structural change tests, Journal of Business and Economics Statistics, 15(1), 60-67.

IMF (2007). World Economic Outlook. Washington (D.C.): IMF, October.

Jeanne O, Masson P (2000). Currency crises, sunspots, and Markov-Switching regimes, Journal of international Economics, 50(2), 327-350.

Kaminsky GL, Lizondo S, Reinhard CM (1998). Leading indicators of currency crises, International Monetary Fund Staff papers 45, 1-48.

Kaminsky GL, Reinhart CM (1999). The twin crises: the causes of banking and balance of payments problems, American Economic Review 89, 473-500.

Kaminsky, GL, Reinhart CM (2000). On crises, contagion, and confusion, Journal of International Economics, 51, 145-168.

Kenneally M, Nhan NT (1986). The strength and stability of the relationships between monetary variables and exchange market pressure reconsidered, Southern Economic Journal, 53(1), 95-109.

Kocenda E, Hanousek J (2011). Foreign news and spillovers in emerging european stock markets. Review of International Economics, 19(1), 170-188.

Konings J, Rizov M, Vandenbussche H (2003). Investment and financial constraints in transition economies: micro evidence from Poland, the Czech Republic, Bulgaria and Romania, Economics Letters, 78, 253-258. 
Kornai J (1992) The Socialist system: The political economy of communism, Princeton University Press, Princeton, NJ.

Kornai J (2001). Hardening the budget constraint: the experience of the post-socialist countries, European Economic Review 45, 1095-1136.

Krugman P (1979). A model of balance-of-payments crisis, Journal of Money, Credit and Banking, 11(August), 311-325.

Lestano L, Jacobs JPAM (2007). Dating currency crises with ad hoc and extreme value-based thresholds: East Asia 1970-2002. International Journal of Finance and Economics, 12: 371-388.

Kamin S B, Schindlerz J, Samuel S (2007). The contribution of domestic and external factors to emerging market currency crises: an early warning systems approach, International Journal of Finance and Economics, 12: 317-336.

Lin CS, Khan HA, Chang RY, Wang YC (2008). A new approach to modeling early warning systems for currency crises: can a machine-learning fuzzy expert system predict the currency crises effectively? Journal of International Money and Finance, In Press.

Lízal L, Svejnar J (2002). Investment, credit rationing, and the soft budget constraint: evidence from Czech panel data, The Review of Economics and Statistics, 84, 353-370.

Mallick S, Moore T (2008). Foreign capital in a growth model, the Review of Development Economics, 12(1), 143-159.

Mody A, Taylor MP (2007). Regional Vulnerability: the case of East Asia, Journal of International Money and Finance, 26, 1292-1310.

Moore T, Wang P (2007). Volatility in stock returns for new EU member states: Markov regime switching model, International Review of Financial Analyses, $16,282-292$.

Obstfeld M (1986). Rational and self-fulfilling balance-of-payments crises. American Economic Review 76, 72-81.

Obstfeld M (1996). Models of currency crises with self-fulfilling features. European Economic Review 40, 1037-1048.

Pentecost E J, Van Hooydonkb C, Van Poeckb A (2001). Measuring and estimating exchange market pressure in the EU, Journal of International Money and Finance, 20 (3), 401-418.

Radelet S, Sachs JD (1998). The East Asian financial crisis: Diagnosis, remedies, prospects, Brookings Papers on Economic Activity: 1. 
Sachs J, Tornell A, Velasco A (1996). Financial crises in emerging markets: The lessons from 1995, Brookings Papers on Economic Activity, 27(1), 147-199.

Sarno L, Taylor MP (1999). Moral hazard, asset price bubbles, capital flows and the East Asian crisis: the first tests, Journal of International Money and finance, 18, 637-657.

Schaffer ME (1998). Do firms in transition have soft budget constraints? A reconsideration of concepts and evidence, Journal of Comparative Economics $26,80-103$.

Stavárek D (2008). Comparative analysis of the exchange market pressure in Central European countries with the Eurozone membership perspective. South East European Journal of Economics and Business, 3, 7-18.

Tanner E (2001). Exchange market pressure and monetary policy: Asia and Latin America in the 1990s, International Monetary Fund Staff papers, 47, 311-333.

Weymark DN (1995). Estimating exchange market pressure and the degree of exchange market intervention for Canada, Journal of International Economics, 39, 273-295.

Weymark DN (1997). Measuring the degree of exchange market intervention in a small open economy, Journal of International Money and Finance, 55-79

Wang P, Moore T (2009). Sudden changes in volatility: the case of five central European stock markets, Journal of International Financial Markets, Institutions and Money, 19, 33-46.

Van Poeck A, Vanneste J, Veiner M (2007). Exchange Rate Regimes and Exchange Market Pressure in the New EU Member States, Journal of Common Market Studies, 45, 459-485. 
Table 1 Estimation of the common factors: Exchange market pressure

\begin{tabular}{|c|c|c|c|c|c|c|c|c|c|}
\hline$\phi_{1}$ & $\begin{array}{l}0.1259 \\
(0.1601)\end{array}$ & $\phi_{2}$ & $\begin{array}{l}-0.0040 \\
(0.0101)\end{array}$ & & & & & & \\
\hline$\psi_{11}$ & $\begin{array}{l}0.1691 \\
(0.1158)\end{array}$ & $\psi_{12}$ & $\begin{array}{l}-0.0072 \\
(0.0098)\end{array}$ & $\sigma_{1}^{2}$ & $\begin{array}{l}0.5765 \\
(0.1261)\end{array}$ & $\lambda_{1}$ & $\begin{array}{l}0.6168 \\
(0.1143)\end{array}$ & $R_{1}^{2}$ & 0.65 \\
\hline$\psi_{21}$ & $\begin{array}{l}0.0814 \\
(0.0811)\end{array}$ & $\psi_{22}$ & $\begin{array}{l}0.0981 \\
(0.0843)\end{array}$ & $\sigma_{2}^{2}$ & $\begin{array}{l}0.9401 \\
(0.1104)\end{array}$ & $\lambda_{2}$ & $\begin{array}{l}0.2055 \\
(0.1062)\end{array}$ & $R_{2}^{2}$ & 0.06 \\
\hline$\psi_{31}$ & $\begin{array}{l}0.0436 \\
(0.0902)\end{array}$ & $\psi_{32}$ & $\begin{array}{l}-0.0005 \\
(0.0020)\end{array}$ & $\sigma_{3}^{2}$ & $\begin{array}{l}0.8643 \\
(0.1097)\end{array}$ & $\lambda_{3}$ & $\begin{array}{l}0.3494 \\
(0.1044)\end{array}$ & $R_{3}^{2}$ & 0.20 \\
\hline$\psi_{41}$ & $\begin{array}{l}-0.0141 \\
(0.0692)\end{array}$ & $\psi_{42}$ & $\begin{array}{l}0.0000 \\
(0.0005)\end{array}$ & $\sigma_{4}^{2}$ & $\begin{array}{l}0.6637 \\
(0.1259)\end{array}$ & $\lambda_{4}$ & $\begin{array}{l}0.5684 \\
(0.1183)\end{array}$ & $R_{4}^{2}$ & 0.54 \\
\hline$\psi_{51}$ & $\begin{array}{l}0.1294 \\
(0.0930)\end{array}$ & $\psi_{52}$ & $\begin{array}{l}0.0577 \\
(0.0945)\end{array}$ & $\sigma_{5}^{2}$ & $\begin{array}{l}0.7673 \\
(0.1067)\end{array}$ & $\lambda_{5}$ & $\begin{array}{l}0.4492 \\
(0.1049)\end{array}$ & $R_{5}^{2}$ & 0.35 \\
\hline
\end{tabular}

Note: Log likelihood 350.7574. Standard errors are in bracket. The order of the idiosyncratic

component is Czeck Republic, Hungary, Poland, Slovkia and Slovenia. $R_{\tilde{i}}^{2}$ ( $i=1$ to 5 ) is the goodness of fit, which is obtained from regressing the individual EMPs on the regional EMP. 
Table 2 Estimation of the common factors: Determinants of exchange market pressure

\begin{tabular}{|c|c|c|c|c|c|c|c|c|c|}
\hline \multicolumn{10}{|c|}{ Ratio of M2 to GDP $(\mathrm{m})$} \\
\hline$\phi_{1}$ & $\begin{array}{l}-0.2192 \\
(0.0940)\end{array}$ & $\phi_{2}$ & $\begin{array}{l}-0.0120 \\
(0.0103)\end{array}$ & & & & & & \\
\hline$\psi_{11}$ & $\begin{array}{l}-0.3697 \\
(0.1421)\end{array}$ & $\psi_{12}$ & $\begin{array}{l}0.0345 \\
(0.1279)\end{array}$ & $\sigma_{1}^{2}$ & $\begin{array}{l}0.1201 \\
0.0265\end{array}$ & $\lambda_{1}$ & $\begin{array}{l}0.8808 \\
(0.0594)\end{array}$ & $R_{1}^{2}$ & 0.93 \\
\hline$\psi_{21}$ & $\begin{array}{l}-0.5022 \\
(0.0937)\end{array}$ & $\psi_{22}$ & $\begin{array}{l}-0.0631 \\
(0.0235)\end{array}$ & $\sigma_{2}^{2}$ & $\begin{array}{l}0.2843 \\
0.0390\end{array}$ & $\lambda_{2}$ & $\begin{array}{l}0.7850 \\
(0.0626)\end{array}$ & $R_{2}^{2}$ & 0.69 \\
\hline$\psi_{31}$ & $\begin{array}{l}-0.5490 \\
(0.0902)\end{array}$ & $\psi_{32}$ & $\begin{array}{l}-0.0753 \\
(0.0247)\end{array}$ & $\sigma_{3}^{2}$ & $\begin{array}{l}0.3711 \\
0.0469\end{array}$ & $\lambda_{3}$ & $\begin{array}{l}0.7286 \\
(0.0643)\end{array}$ & $R_{3}^{2}$ & 0.56 \\
\hline$\psi_{41}$ & $\begin{array}{l}-0.3169 \\
(0.1252)\end{array}$ & $\psi_{42}$ & $\begin{array}{l}-0.0251 \\
(0.0198)\end{array}$ & $\sigma_{4}^{2}$ & $\begin{array}{l}0.1749 \\
0.0315\end{array}$ & $\lambda_{4}$ & $\begin{array}{l}0.9041 \\
(0.0633)\end{array}$ & $R_{4}^{2}$ & 0.87 \\
\hline$\psi_{51}$ & $\begin{array}{l}-0.6043 \\
(0.0798) \\
\end{array}$ & $\psi_{52}$ & $\begin{array}{l}-0.0494 \\
(0.0803)\end{array}$ & $\sigma_{5}^{2}$ & $\begin{array}{l}0.6531 \\
0.0742\end{array}$ & $\lambda_{5}$ & $\begin{array}{l}0.0396 \\
(0.0634)\end{array}$ & $R_{5}^{2}$ & 0.03 \\
\hline \multicolumn{10}{|c|}{ Ratio of Foreign liability to GDP $(f l)$} \\
\hline$\phi_{1}$ & $\begin{array}{l}-0.7211 \\
(0.1659)\end{array}$ & $\phi_{2}$ & $\begin{array}{l}-0.1300 \\
(0.0598)\end{array}$ & & & & & & \\
\hline$\psi_{11}$ & $\begin{array}{l}-0.3946 \\
(0.0974)\end{array}$ & $\psi_{12}$ & $\begin{array}{l}-0.0389 \\
(0.0192)\end{array}$ & $\sigma_{1}^{2}$ & $\begin{array}{l}0.6726 \\
0.1139\end{array}$ & $\lambda_{1}$ & $\begin{array}{l}-0.3894 \\
(0.1264)\end{array}$ & $R_{1}^{2}$ & 0.43 \\
\hline$\psi_{21}$ & $\begin{array}{l}-0.2367 \\
(0.0871)\end{array}$ & $\psi_{22}$ & $\begin{array}{l}-0.0140 \\
(0.0103)\end{array}$ & $\sigma_{2}^{2}$ & $\begin{array}{l}0.9396 \\
0.1071\end{array}$ & $\lambda_{2}$ & $\begin{array}{l}-0.0467 \\
(0.1058)\end{array}$ & $R_{2}^{2}$ & 0.02 \\
\hline$\psi_{31}$ & $\begin{array}{l}-0.3681 \\
(0.1182)\end{array}$ & $\psi_{32}$ & $\begin{array}{l}-0.0339 \\
(0.0218)\end{array}$ & $\sigma_{3}^{2}$ & $\begin{array}{l}0.5331 \\
0.1273\end{array}$ & $\lambda_{3}$ & $\begin{array}{l}0.4835 \\
(0.1306)\end{array}$ & $R_{3}^{2}$ & 0.72 \\
\hline$\psi_{41}$ & $\begin{array}{l}-0.4312 \\
(0.0907)\end{array}$ & $\psi_{42}$ & $\begin{array}{l}-0.0465 \\
(0.0196)\end{array}$ & $\sigma_{4}^{2}$ & $\begin{array}{l}0.7399 \\
0.0959\end{array}$ & $\lambda_{4}$ & $\begin{array}{l}-0.2237 \\
(0.1138)\end{array}$ & $R_{4}^{2}$ & 0.21 \\
\hline$\psi_{51}$ & $\begin{array}{l}-0.2717 \\
(0.0875)\end{array}$ & $\psi_{52}$ & $\begin{array}{l}-0.0185 \\
(0.0119)\end{array}$ & $\sigma_{5}^{2}$ & $\begin{array}{l}0.8514 \\
0.1051\end{array}$ & $\lambda_{5}$ & $\begin{array}{l}0.1959 \\
(0.1054)\end{array}$ & $R_{5}^{2}$ & 0.14 \\
\hline \multicolumn{10}{|c|}{ Real domestic credit $(d c)$} \\
\hline$\phi_{1}$ & $\begin{array}{l}-0.0584 \\
(0.1759)\end{array}$ & $\phi_{2}$ & $\begin{array}{l}-0.0009 \\
(0.0051)\end{array}$ & & & & & & \\
\hline$\psi_{11}$ & $\begin{array}{l}-0.0322 \\
(0.0841)\end{array}$ & $\psi_{12}$ & $\begin{array}{l}-0.0003 \\
(0.0014)\end{array}$ & $\sigma_{1}^{2}$ & $\begin{array}{l}0.9328 \\
(0.1147)\end{array}$ & $\lambda_{1}$ & $\begin{array}{l}0.2439 \\
(0.1191)\end{array}$ & $R_{1}^{2}$ & 0.08 \\
\hline$\psi_{21}$ & $\begin{array}{l}0.1702 \\
(0.0801)\end{array}$ & $\psi_{22}$ & $\begin{array}{l}0.2066 \\
(0.0804)\end{array}$ & $\sigma_{2}^{2}$ & $\begin{array}{l}0.8649 \\
(0.1087)\end{array}$ & $\lambda_{2}$ & $\begin{array}{l}0.2128 \\
(0.1258)\end{array}$ & $R_{2}^{2}$ & 0.06 \\
\hline$\psi_{31}$ & $\begin{array}{l}-0.3004 \\
(0.4529)\end{array}$ & $\psi_{32}$ & $\begin{array}{l}-0.0226 \\
(0.0680)\end{array}$ & $\sigma_{3}^{2}$ & $\begin{array}{l}0.2155 \\
(0.5729)\end{array}$ & $\lambda_{3}$ & $\begin{array}{l}0.8695 \\
(0.3385)\end{array}$ & $R_{3}^{2}$ & 0.98 \\
\hline$\psi_{41}$ & $\begin{array}{l}0.0465 \\
(0.0869)\end{array}$ & $\psi_{42}$ & $\begin{array}{l}-0.0005 \\
(0.0020)\end{array}$ & $\sigma_{4}^{2}$ & $\begin{array}{l}0.9864 \\
(0.1124)\end{array}$ & $\lambda_{4}$ & $\begin{array}{l}0.0655 \\
(0.1036)\end{array}$ & $R_{4}^{2}$ & 0.01 \\
\hline$\psi_{51}$ & $\begin{array}{l}-0.0612 \\
(0.0812)\end{array}$ & $\psi_{52}$ & $\begin{array}{l}0.0299 \\
(0.0789)\end{array}$ & $\sigma_{5}^{2}$ & $\begin{array}{l}0.9753 \\
(0.1112)\end{array}$ & $\lambda_{5}$ & $\begin{array}{l}0.1078 \\
(0.0920)\end{array}$ & $R_{5}^{2}$ & 0.21 \\
\hline
\end{tabular}

Real stock market (sp)

$\begin{array}{llllllllll}\phi_{1} & 0.2831 & \phi_{2} & -0.0200 & & & & & & \\ & (0.1112) & & (0.0157) & & & & & \\ \psi_{11} & 0.0956 & \psi_{12} & -0.0023 & \sigma_{1}^{2} & 0.3128 & \lambda_{1} & 0.7970 & R_{1}^{2} & 0.81 \\ & (0.1275) & & (0.0061) & & (0.0628) & & (0.0715) & & \\ \psi_{21} & -0.0635 & \psi_{22} & -0.0010 & \sigma_{2}^{2} & 0.3829 & \lambda_{2} & 0.7508 & R_{2}^{2} & 0.73 \\ & (0.1106) & & (0.0035) & & (0.0660) & & (0.0737) & & \\ \psi_{31} & -0.1401 & \psi_{32} & 0.0822 & \sigma_{3}^{2} & 0.4581 & \lambda_{3} & 0.7197 & R_{3}^{2} & 0.62 \\ & (0.1045) & & (0.1003) & & (0.0711) & & (0.0731) & & \\ \psi_{41} & 0.1079 & \psi_{42} & -0.0029 & \sigma_{4}^{2} & 0.7566 & \lambda_{4} & 0.4660 & R_{4}^{2} & 0.27 \\ & (0.1176) & & (0.0063) & & (0.0917) & & (0.0809) & & \\ \psi_{51} & 0.0114 & \psi_{52} & 0.0548 & \sigma_{5}^{2} & 0.9434 & \lambda_{5} & 0.2162 & R_{5}^{2} & 0.06 \\ & (0.0839) & & (0.0834) & & (0.1086) & & (0.0886) & & \end{array}$

Ratio of domestic credit to GDP $($ dcy $)$ 


\begin{tabular}{|c|c|c|c|c|c|c|c|c|c|}
\hline$\phi_{1}$ & $\begin{array}{l}-0.2558 \\
(0.0954)\end{array}$ & $\phi_{2}$ & $\begin{array}{l}-0.0164 \\
(0.0122)\end{array}$ & & & & & & \\
\hline$\psi_{11}$ & $\begin{array}{l}-0.4761 \\
(0.1585)\end{array}$ & $\psi_{12}$ & $\begin{array}{l}-0.0567 \\
(0.0377)\end{array}$ & $\sigma_{1}^{2}$ & $\begin{array}{l}0.1268 \\
(0.0357)\end{array}$ & $\lambda_{1}$ & $\begin{array}{l}0.8699 \\
(0.0602)\end{array}$ & $R_{1}^{2}$ & 0.25 \\
\hline$\psi_{21}$ & $\begin{array}{l}-0.4343 \\
(0.0944)\end{array}$ & $\psi_{22}$ & $\begin{array}{l}-0.0472 \\
(0.0205)\end{array}$ & $\sigma_{2}^{2}$ & $\begin{array}{l}0.3341 \\
(0.0467)\end{array}$ & $\lambda_{2}$ & $\begin{array}{l}0.7519 \\
(0.0652)\end{array}$ & $R_{2}^{2}$ & 0.18 \\
\hline$\psi_{31}$ & $\begin{array}{l}-0.5718 \\
(0.0910)\end{array}$ & $\psi_{32}$ & $\begin{array}{l}-0.0817 \\
(0.0260)\end{array}$ & $\sigma_{3}^{2}$ & $\begin{array}{l}0.3855 \\
(0.0511)\end{array}$ & $\lambda_{3}$ & $\begin{array}{r}0.7029 \\
(0.0652)\end{array}$ & $R_{3}^{2}$ & 0.57 \\
\hline$\psi_{41}$ & $\begin{array}{l}0.0433 \\
(0.0966)\end{array}$ & $\psi_{42}$ & $\begin{array}{l}-0.0005 \\
(0.0021)\end{array}$ & $\sigma_{4}^{2}$ & $\begin{array}{r}0.3647 \\
(0.0520)\end{array}$ & $\lambda_{4}$ & $\begin{array}{l}0.7666 \\
(0.0676)\end{array}$ & $R_{4}^{2}$ & 0.62 \\
\hline$\psi_{51}$ & $\begin{array}{l}-0.2051 \\
(0.0808)\end{array}$ & $\psi_{52}$ & $\begin{array}{l}0.0357 \\
(0.0795)\end{array}$ & $\sigma_{5}^{2}$ & $\begin{array}{l}0.9390 \\
(0.1068)\end{array}$ & $\lambda_{5}$ & $\begin{array}{c}0.1063 \\
(0.0815)\end{array}$ & $R_{5}^{2}$ & 0.27 \\
\hline
\end{tabular}

Note: Standard errors are in bracket. The order of the idiosyncratic component is Czeck Republic,

Hungary, Poland, Slovkia and Slovenia. $R_{\tilde{i}}^{2}(i=1$ to 5 ) is the goodness of fit, which is obtained from regressing the country-specific determinants on the extracted common factor of the determinants in this region. 
Table 3 Country specific and Commonfactor determinants: dependent variable emp

\begin{tabular}{|c|c|c|c|c|c|c|}
\hline & Hungary & Czech Rep. & Poland & Slovakia & Slovenia & Regional \\
\hline constant & $\begin{array}{r}1.193 \\
(3.310)\end{array}$ & $\begin{array}{r}-0.776 \\
(1.899)\end{array}$ & $\begin{array}{r}-1.121 \\
(3.366)\end{array}$ & $\begin{array}{r}-0.694 \\
(1.659)\end{array}$ & $\begin{array}{r}-0.798 \\
(2.070)\end{array}$ & $\begin{array}{l}-0.373 \\
(2.217)\end{array}$ \\
\hline$e m p_{t-1}$ & & $\begin{array}{r}0.184 \\
(2.352)\end{array}$ & $\begin{array}{r}0.108 \\
(1.496)\end{array}$ & & $\begin{array}{r}0.096 \\
(1.328)\end{array}$ & $\begin{array}{r}0.133 \\
(1.666)\end{array}$ \\
\hline$s p_{t}$ & $\begin{array}{r}-5.192 \\
(1.781)\end{array}$ & $\begin{array}{r}-2.447 \\
(1.334)\end{array}$ & $\begin{array}{r}-6.356 \\
(4.038)\end{array}$ & $\begin{array}{r}-2.374 \\
(1.473)\end{array}$ & $\begin{array}{r}-4.254 \\
(1.991)\end{array}$ & na \\
\hline$f l$ & $\begin{array}{r}2.373 \\
(4.647)\end{array}$ & & $\begin{array}{r}0.395 \\
(1.708)\end{array}$ & $\begin{array}{r}0.502 \\
(1.529)\end{array}$ & & na \\
\hline$f d i$ & & $\begin{array}{r}-0.071 \\
(1.452)\end{array}$ & & $\begin{array}{r}-0.097 \\
(1.809)\end{array}$ & $\begin{array}{r}-0.149 \\
(1.651)\end{array}$ & na \\
\hline$d c$ & & $\begin{array}{l}18.514 \\
(2.892)\end{array}$ & & $\begin{array}{r}6.604 \\
(1.630)\end{array}$ & $\begin{array}{r}23.520 \\
(3.111)\end{array}$ & na \\
\hline$d c y$ & $\begin{array}{r}12.598 \\
(1.915)\end{array}$ & & $\begin{array}{r}17.528 \\
(1.759)\end{array}$ & & & na \\
\hline$m_{t}$ & $\begin{array}{r}-11.990 \\
(1.837)\end{array}$ & $\begin{array}{r}-3.520 \\
(2.241)\end{array}$ & $\begin{array}{r}-23.224 \\
(2.307)\end{array}$ & & $\begin{array}{r}-3.316 \\
(1.678)\end{array}$ & na \\
\hline oil & & $\begin{array}{r}1.621 \\
(1.574)\end{array}$ & $\begin{array}{r}2.136 \\
(1.818)\end{array}$ & & & \\
\hline $\begin{array}{l}s p^{c f} \\
f l^{c f}\end{array}$ & $\begin{array}{r}-0.620 \\
(2.134)\end{array}$ & & & $\begin{array}{r}-0.513 \\
(2.278)\end{array}$ & & $\begin{array}{r}-0.143 \\
(1.872)\end{array}$ \\
\hline$d c^{c f}$ & $\begin{array}{r}0.276 \\
(1.654)\end{array}$ & $\begin{array}{r}0.241 \\
(2.263)\end{array}$ & $\begin{array}{r}0.243 \\
(1.395)\end{array}$ & & & \\
\hline$d c y^{c f}$ & $\begin{array}{r}0.301 \\
(3.263)\end{array}$ & & $\begin{array}{r}0.195 \\
(2.297)\end{array}$ & $\begin{array}{r}0.221 \\
(2.004)\end{array}$ & $\begin{array}{r}0.208 \\
(2.206)\end{array}$ & $\begin{array}{r}0.102 \\
(2.370)\end{array}$ \\
\hline$m^{c f}$ & & & & & & $\begin{array}{r}-0.121 \\
(1.811) \\
\end{array}$ \\
\hline$R^{2}$ & 0.251 & 0.153 & 0.265 & 0.182 & 0.157 & 0.071 \\
\hline $\begin{array}{l}\text { Serial cor. } \\
\chi^{2} \text { (1) }\end{array}$ & $\begin{array}{r}0.115 \\
{[0.734]}\end{array}$ & $\begin{array}{r}0.055 \\
{[0.814]}\end{array}$ & $\begin{array}{r}5.204 \\
{[0.023]}\end{array}$ & $\begin{array}{r}0.592 \\
{[0.442]}\end{array}$ & $\begin{array}{r}0.054 \\
{[0.817]}\end{array}$ & $\begin{array}{r}2.453 \\
{[0.117]}\end{array}$ \\
\hline$\chi^{2}(2)$ & $\begin{array}{r}0.354 \\
{[0.838]}\end{array}$ & $\begin{array}{r}0.350 \\
{[0.840]}\end{array}$ & $\begin{array}{r}5.480 \\
{[0.065]}\end{array}$ & $\begin{array}{r}3.074 \\
{[0.215]}\end{array}$ & $\begin{array}{r}0.610 \\
{[0.737]}\end{array}$ & $\begin{array}{r}2.459 \\
{[0.292]}\end{array}$ \\
\hline Hetero. & $\begin{array}{r}5.741 \\
{[0.570]}\end{array}$ & $\begin{array}{r}21.767 \\
{[0.003]}\end{array}$ & $\begin{array}{r}7.532 \\
{[0.480]}\end{array}$ & $\begin{array}{r}3.505 \\
{[0.743]}\end{array}$ & $\begin{array}{c}33.063 \\
{[0.000]}\end{array}$ & $\begin{array}{r}4.823 \\
{[0.306]}\end{array}$ \\
\hline Ramsey & $1.3 \mathrm{E}-05$ & 0.050 & 0.854 & 0.951 & 3.066 & 3.324 \\
\hline RESET & [0.997] & [0.824] & [0.357] & [0.331] & [0.082] & {$[0.070]$} \\
\hline $\begin{array}{l}\text { Hausman } \\
\text { Exogeneity }\end{array}$ & {$[0.733]$} & [0.511] & {$[0.065]$} & {$[0.570]$} & {$[0.640]$} & [0.123] \\
\hline
\end{tabular}

Note: $e m p_{t-1}$ : the lagged dependent variable, $s p$ : real stock market index, $d c:$ the growth of real domestic credit, $d c y$ : ratio of credit to GDP, $m$ : ratio of M2 to GDP, $f l$ : ratio of total foreign liability to money stock, $f d i$ : ratio of net FDI flows to GDP, oil: oil prices, the superscript ' $c f$ ': common factor variables.

Sample period: 1994.1 to 2006.12. na: not applicable. Figures in parentheses are t-statistics ( ) for coefficients, and probability values [ ] for diagnostic tests. Breusch-Pagan-Godfrey heteroskedasticity test, $\chi^{2}$. White Heteroskedasticity-Consistent Standard Errors are estimated where there is presence of heteroskedasticity. Breusch-Godfrey: Serial correlation LM test, distributed as $\chi^{2}(1)$ and $\chi^{2}(2)$. Ramsey RESET is the F-test. 
Table 4 Structural break tests

Chow forecast F-test [prob. Value]

\begin{tabular}{|c|c|c|c|c|c|c|}
\hline $\begin{array}{l}\text { Forecast } \\
\text { period }\end{array}$ & Hungary & Czech & Poland & Slovakia & Slovenia & Regional \\
\hline \multirow{2}{*}{$\begin{array}{l}1996.1- \\
2006.12\end{array}$} & 0.547 & 1.713 & 1.830 & 0.648 & 0.366 & 0.937 \\
\hline & [0.963] & [0.126] & [0.109] & [0.904] & [0.999] & {$[0.608]$} \\
\hline \multirow{2}{*}{$\begin{array}{l}1998.1- \\
2006.12\end{array}$} & 0.934 & 0.434 & 1.217 & 0.511 & 0.215 & 0.475 \\
\hline & [0.617] & $[1.000])$ & {$[0.252]$} & [0.996] & {$[1.000]$} & {$[0.999]$} \\
\hline \multirow{2}{*}{$\begin{array}{l}2000.1- \\
2006.12\end{array}$} & 0.865 & 0.345 & 0.442 & 0.314 & 0.337 & 0.456 \\
\hline & [0.733] & {$[1.000]$} & [1.000] & [1.000] & {$[1.000]$} & {$[1.000]$} \\
\hline \multirow{2}{*}{$\begin{array}{l}2002.1- \\
2006.12\end{array}$} & 1.267 & 0.455 & 0.466 & 0.335 & 0.368 & 0.590 \\
\hline & {$[0.157]$} & [0.999] & [0.999] & [1.000] & [1.000] & {$[0.985]$} \\
\hline \multirow{2}{*}{$\begin{array}{l}2004.1- \\
2006.12\end{array}$} & 0.960 & 0.294 & 0.654 & 0.411 & 0.340 & 0.440 \\
\hline & {$[0.541]$} & [1.000] & [0.927] & {$[0.998]$} & [1.000] & {$[0.997]$} \\
\hline \multicolumn{7}{|c|}{ Quandt-Andrews LR F-test [prob. Value] } \\
\hline & $\begin{array}{c}1.739 \\
{[1.000\}}\end{array}$ & $\begin{array}{c}1.237 \\
{[1.000]}\end{array}$ & $\begin{array}{c}1.140 \\
{[1.000]}\end{array}$ & $\begin{array}{c}1.228 \\
{[1.000]}\end{array}$ & $\begin{array}{c}1.894 \\
{[1.000]}\end{array}$ & $\begin{array}{c}1.175 \\
{[1.000]}\end{array}$ \\
\hline
\end{tabular}

Notes: Chow forecast F-test requires estimation over a sub-sample. Significance levels are based on $F=\frac{\left(R S S_{T}-R S S_{T_{1}}\right) / T_{2}}{R S S_{T_{1}} /\left(T_{1}-k\right)}$, where $R S S_{T}$ is the residual sum of squares for the whole sample, $R S S_{T_{1}}$ is the residual sum of squares for the first $T_{1}$ observations. The number in brackets is the probability of finding a value in excess of $\mathrm{F}$.

In the Quandt-Andrews test (Andrews, 1993), a single Chow breakpoint test is performed at every observation between two dates, $\tau_{1}$ and $\tau_{2}$. The $k$ test statistics are then summarized into one test statistic for a test against the null hypothesis of no breakpoints between $\tau_{1}$ and $\tau_{2}$. The statistic is the average of the individual $\mathbf{F}$-statistics:

Ave $F=\frac{1}{k} \sum_{\tau=\tau_{1}}^{T_{2}} F(\tau)$

Hansen (1997) p-values are used. 
Figure 1 Exchange market pressure
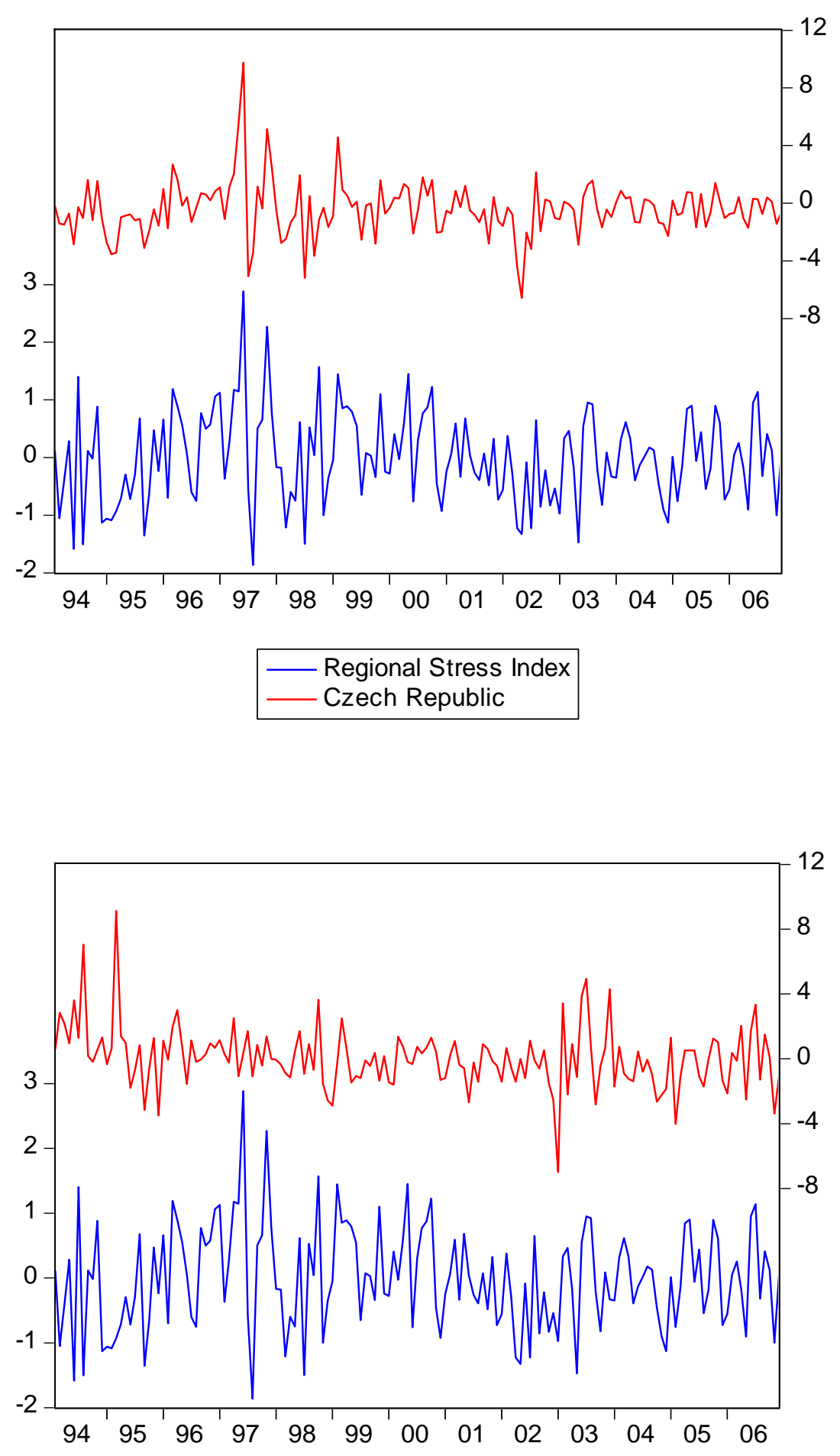

_ Regional Stress Index _ Hungary 

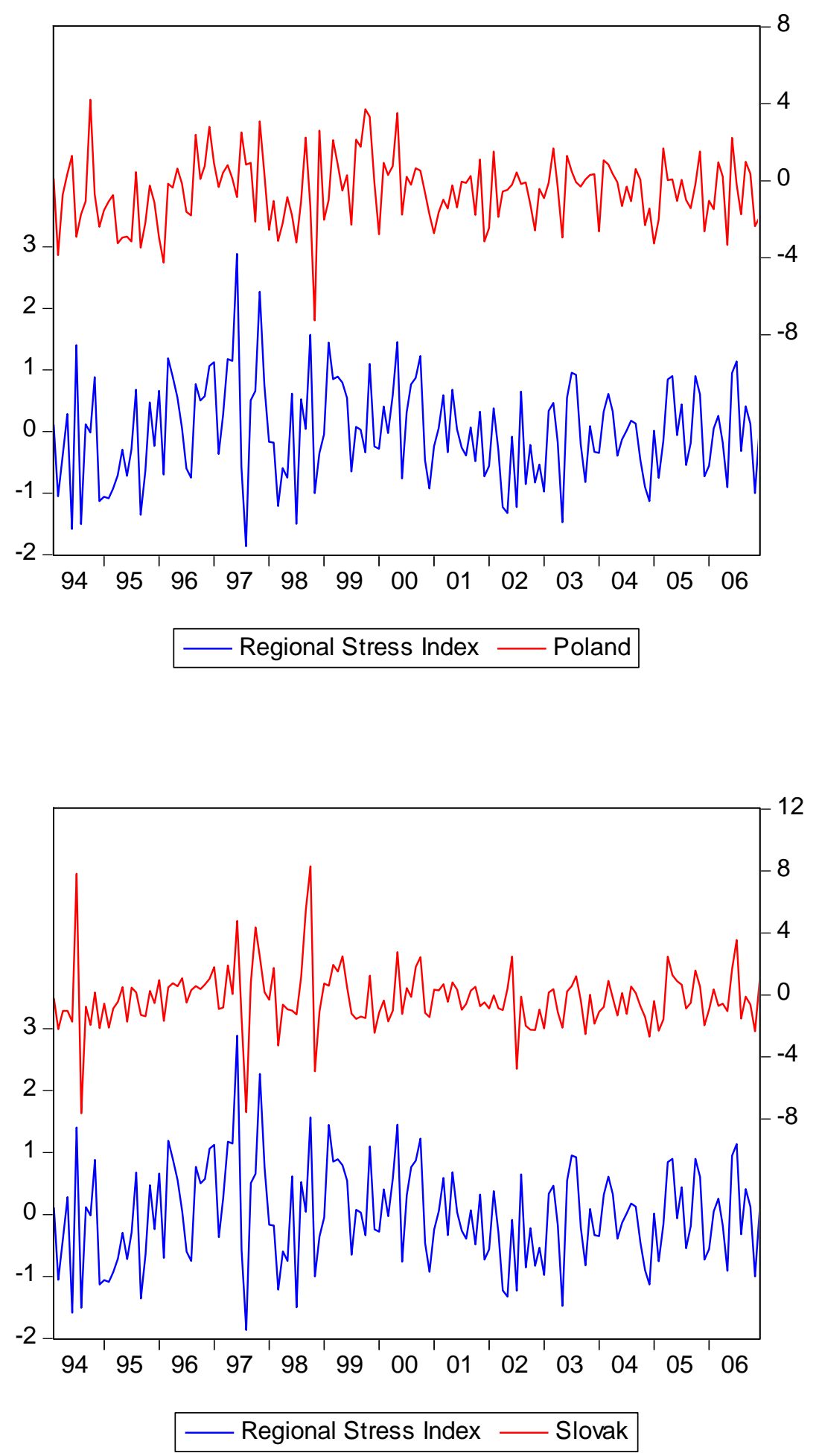


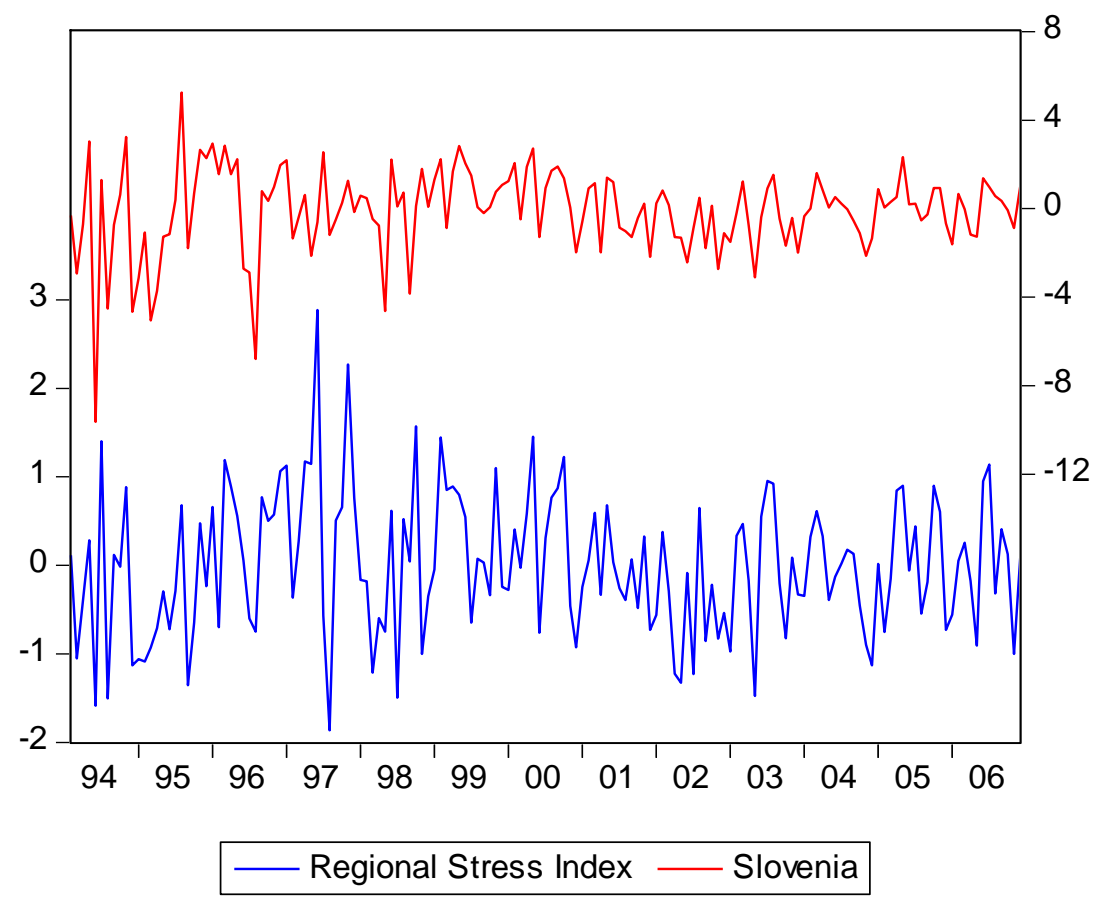

Note: The scale of the regional EMP is on the lower left side and the scale of the country-specific EMP is on the upper right side. 


\section{Figure 2 CUSUM test with $5 \%$ critical lines}

Hungary

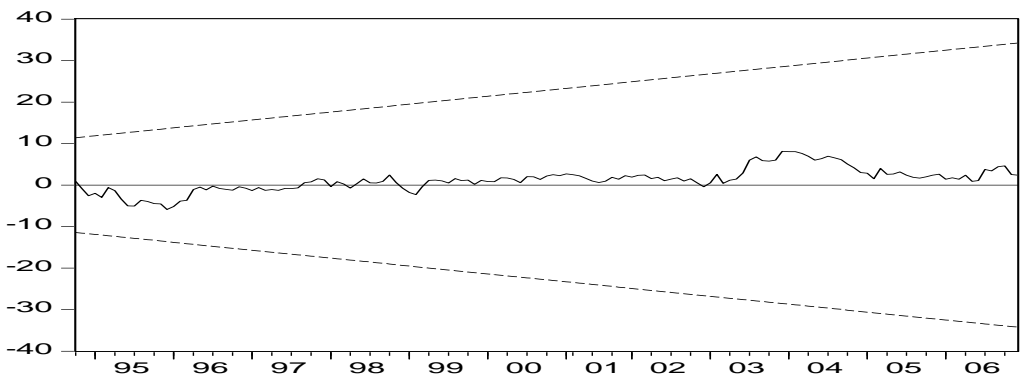

The Czech Republic

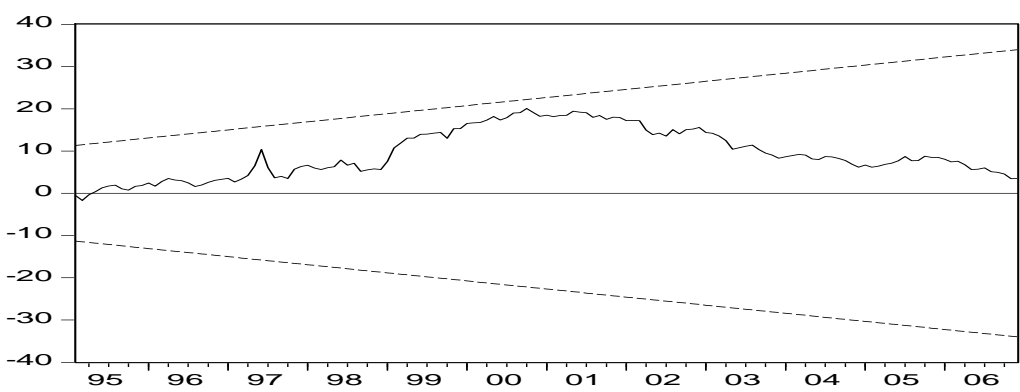

Poland

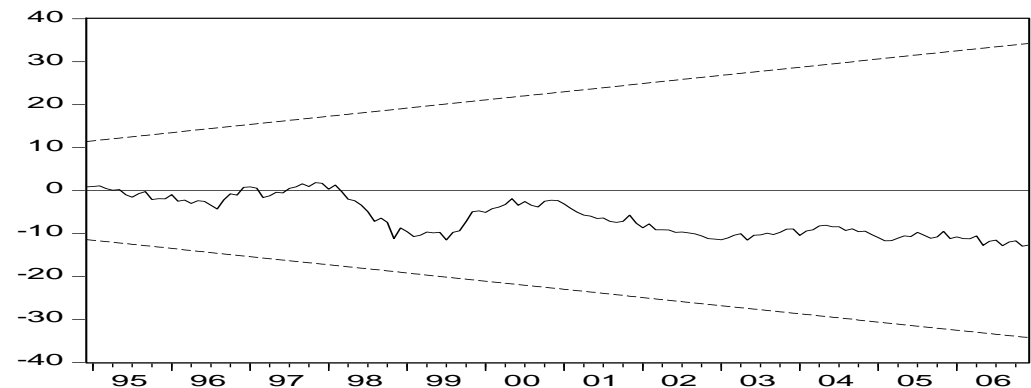

Slovakia

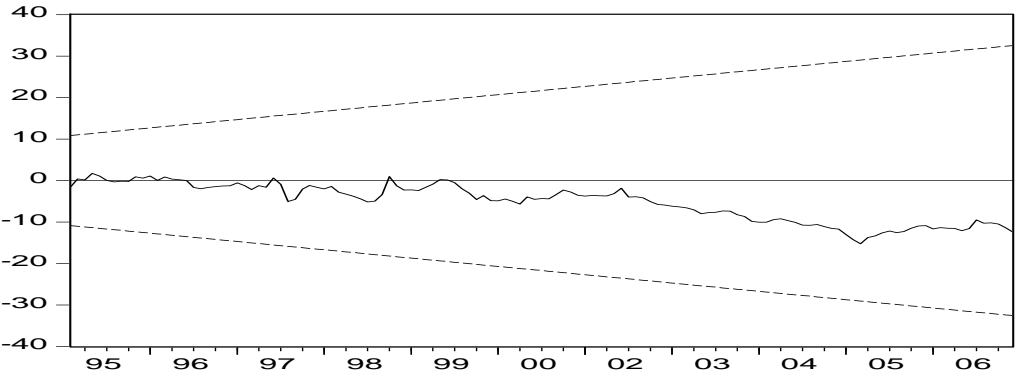




\section{Slovenia}

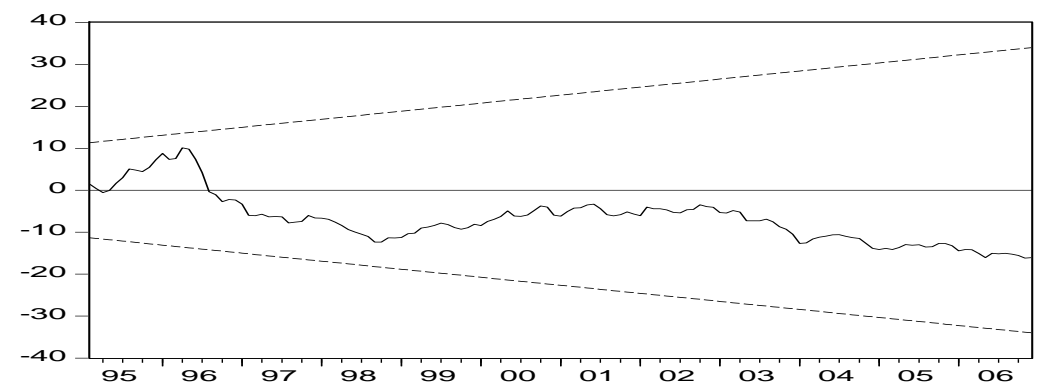

Regional EMP

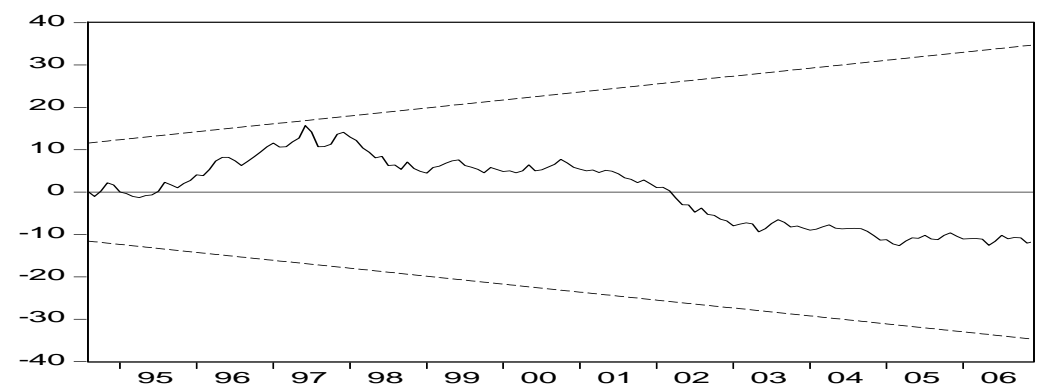

